\title{
Sprawozdanie z obrad grupy tematycznej Od socjologii wojny i wojska do socjologii grup dyspozycyjnych i bezpieczeństwa, XVII Ogólnopolski Zjazd Socjologiczny we Wrocławiu, 11-14 września 2019 roku
}

\section{https://doi.org/10.19195/2083-7763.10.19}

W dniach 11-14 września 2019 roku we Wrocławiu odbył się XVII Ogólnopolski Zjazd Socjologiczny pod hasłem Ja. My. Oni? Podmiotowość, tożsamość, przynależność organizowany przez Polskie Towarzystwo Socjologiczne i Instytut Socjologii Uniwersytetu Wrocławskiego. Obfitował on w wiele wydarzeń, paneli, grup tematycznych i sympozjów. Swoje miejsce znalazła tu również tematyka socjologicznych aspektów bezpieczeństwa podejmowana między innymi w ramach obrad grupy tematycznej nr G65 Od socjologii wojny i wojska do socjologii grup dyspozycyjnych i bezpieczeństwa prowadzonej przez prof. Adama Kołodziejczyka (Wojskowa Akademia Techniczna) i Jana Maciejewskiego (Uniwersytet Wrocławski) oraz dr. Piotra Pieńkowskiego (Uniwersytet Wrocławski).

W pierwszym dniu zjazdu (11 września) organizatorzy otworzyli obrady i zachęcili do aktywnej dyskusji na temat przedstawianych zagadnień. Jako pierwsza wystąpiła dr Aneta Baranowska (Uniwersytet Kazimierza Wielkiego w Bydgoszczy) z referatem Polska socjologia wojska - osobliwości narodzin i kształtowanie się subdyscypliny. Wskazała w nim na historyczne aspekty instytucjonalizacji socjologii wojska w Polsce, a także na jej współczesną tożsamość. Kolejny referat przedstawił dr Marcin Gacek (Uniwersytet Śląski w Katowicach), a jego przedmiotem była Socjologia wojny w myśli Raymonda Arona. Penser la guerre, Clausewitz. Koncentrując się na dorobku wybitnego francuskiego myśliciela, dokonał analizy aktualności wątków dotyczących problematyki wojny i pokoju. Ograniczenia $i$ wyzwania badawcze socjologii grup dyspozycyjnych określiła prof. Danuta Walczak-Duraj (Uniwersytet Łódzki). Zdaniem prelegentki mają one charakter wyjątkowy, wyróżniający się na tle innych subdyscyplin socjologicznych. Magdalena Fiternicka-Gorzko (Akademia Pomorska w Słupsku) oceniła Przydatność perspektywy biograficznej w badaniu grup dyspozycyjnych. Wykazała specyfikę badanej kategorii na podstawie materiału empirycznego (wywiady prowadzone metodą oral history) z okresu transformacji systemowej. W ostatnim referacie tego dnia mgr Mariusz Busiło (Polska Izba Informatyki i Telekomunikacji w Warszawie) omówił, jak przebiega Cyfrowa wojna informacyjna na przykładzie protestów przeciwko sieciom łaczności $5 G$ - wybrane aspekty. Podkreślił związek między protestami przeciwko sieci 5G i innymi ruchami posługującymi się dezinformacją. Następnie odbyła się dyskusja na temat przedstawionych referatów. Po zakończeniu obrad uczestnicy udali się do restauracji Orbita na uroczystą kolację.

W drugim dniu obrad (12 września) prof. Jadwiga Mazur (Uniwersytet Pedagogiczny im. KEN w Krakowie) wygłosiła referat Wykluczenie społeczne jako potencjalna przyczyna zagrożenia bezpieczeństwa. Zdaniem prelegentki marginalizacja może zdynamizować istniejące zagrożenia i przyczynić się do powstawania nowych. Dr hab. Urszula Soler (Katolicki Uniwersytet Lubelski Jana Pawła II) w wystąpieniu Legia Akademicka przykładem studenckich rezerw czasu wojny przedstawiła funkcjonowanie tej ochotniczej formacji. Historia organizacji proobronnych sięga czasów zaborów. Współcześnie przeżywają one renesans w związku z dynamicznie zmieniającą się sytuacją bezpieczeństwa. Policja

Forum Socjologiczne 10, 2020

(C) for this edition by CNS 
jako grupa dyspozycyjna i gwarant bezpieczeństwa - ujęcie neoinstytucjonalne stała się przedmiotem badań dr. Tomasza Kołodzieja (Uniwersytet Zielonogórski). Wskazał on na strukturalne uwarunkowania zmian w zakresie zapewniania bezpieczeństwa wewnętrznego przez tę formację. Blok referatów zamknął dr Daniel Wicenty (Uniwersytet Gdański, Instytut Pamięci Narodowej) wystąpieniem Środowisko Służby Bezpieczeństwa: dyspozycyjność i funkcjonalność pod koniec PRL i u początków III RP. Z perspektywy socjologicznej dokonał analizy cech grupy, taktyk funkcjonariuszy oraz sytuacji po 1990 roku. Po części dyskusyjnej nastąpiło oficjalne zamknięcie obrad grupy tematycznej. W kolejnych dniach uczestnicy brali udział w pozostałych wydarzeniach zjazdowych, między innymi w obradach innych grup podejmujących tematykę bezpieczeństwa, a także w zebraniu Sekcji Socjologicznych Problemów Bezpieczeństwa Narodowego Polskiego Towarzystwa Socjologicznego.

Piotr Pieńkowski

ORCID: 0000-0002-1719-330X

piotr.pienkowski@uwr.edu.pl

\section{Sprawozdanie z XVII Międzynarodowego Seminarium Metodologicznego Metodologia badań systemów społecznych, Wrocław, 12 grudnia 2019 roku}

\section{https://doi.org/10.19195/2083-7763.10.20}

Dnia 12 grudnia 2019 roku w sali Oratorium Marianum Uniwersytetu Wrocławskiego odbyło się XVII Międzynarodowe Seminarium z cyklu Metodologia badań systemów społecznych organizowane przez Zakład Socjologii Grup Dyspozycyjnych Instytutu Socjologii Uniwersytetu Wrocławskiego, Sekcję Socjologicznych Problemów Bezpieczeństwa Narodowego Polskiego Towarzystwa Socjologicznego oraz Akademickie Koło Naukowe „Security\&Society”. Współorganizatorami byli Akadémia ozbrojených síl, Slovenska Republika, Zakład Socjologii Edukacji IS UWr i Polskie Towarzystwo Socjologiczne - Oddział Wrocławski.

Przybyło wielu znamienitych gości, między innymi: rektor Uniwersytetu Wrocławskiego prof. Adam Jezierski, dziekan Wydziału Nauk Społecznych UWr prof. Robert Wiszniowski, rektor PWSZ w Nysie prof. Przemysław Malinowski, pełnomocnik rektora PWSZ w Nysie prof. Tadeusz Iwanek, dziekan PWSZ w Raciborzu dr Sabina Musioł, dziekan PWSZ w Kaliszu prof. Jarosław Wołejszo, dziekan PWSZ w Głogowie dr Adam Bujak, dyrektor LO im. Kazimierza Jagiellończyka w Sieradzu Grzegorz Pietrucha wraz z dwiema klasami maturzystów. Należy podkreślić obecność władz lokalnych odpowiedzialnych za politykę bezpieczeństwa ekologicznego w osobach pani starosty powiatu Zduńska Wola Hanny Iwaniuk oraz prezydenta miasta Zduńska Wola Konrada Pokory, którzy aktywnie brali udział w dyskusji, wskazując na ograniczenia prawno-ekonomiczne w stosowaniu skutecznych narzędzi w walce ze smogiem. 